\title{
Affective constructions of justice: ISIS-families and the law in the Finnish public debate
}

OÑATI SOCIO-LEGAL SERIES, VOLUME 11 ISSUE 4 (2021), 1036-1065: MiNORITY FAMILIES AND THE LAW: INTERACTIONS OF ETHNIC, RELIGIOUS, AND CULTURAL MINORITIES WITH LAW AND STATE INSTITUTIONS DOI LINK: HTTPS://DOI.ORG/10.35295/OSLS.IISL/0000-0000-0000-1159

RECEIVED 19 DECEMBER 2019, ACCEPTED 05 NOVEMBER 2020

\section{SANNA MUSTASAARI* (iD)}

\section{Abstract}

This article examines the political process and public debate in Finland concerning the Finnish women and children held captive in the refugee camp of Al-Hol in north-east Syria. The article studies the role of affect in the process of constructing justice in these debates. It argues that the debate demonstrates an affective process of bordering, in which a non-belonging and essentially non-Finnish identity was affectively constructed to the mothers, who were depicted as "converts" and "jihadists". Emotions such as compassion were mobilised in the process with ambiguous outcomes. On the one hand, reference to compassion served the conservative agenda of attaching rights to worthiness, on the other hand reference to compassion towards the figure of the innocent child served to isolate the children from their mothers. In the legal context, the affectively constructed identities of the mothers as non-belonging were relevant to how the issue of rights and legal obligations of the state became perceived as something belonging to the realm of national law or international law.

\section{Key words}

Children's rights; law and affect; foreign combatants; Syria

\section{Resumen}

Este artículo examina el proceso político y el debate público de Finlandia sobre las mujeres y niños finlandeses en cautividad en el campo de refugiados de Al-Hol, al nordeste de Siria. El artículo estudia el rol del afecto en el proceso de construcción de justicia en estos debates. Se argumenta que el debate pone de manifiesto un proceso

Writing this article would not have been possible without the support and wise comments of several colleagues and visiting scholars at the Center for the History of Emotions at the Max Planck Institute for Human Development in Berlin and the Department of Law and Anthropology at the Max Planck Institute for Social Anthropology in Halle. In addition, I thank Dr. Miia Halme-Tuomisaari, Dr. Tiina Seppälä, Dr. Samuli Hurri and Associate Professor Mulki Al-Sharmani as well as the anonymous reviewers and the editor of this special issue, Iris Sportel, for their insightful comments and critique.

*Sanna Mustasaari, University of Eastern Finland. Email address: sanna.mustasaari@uef.fi 
afectivo de construcción de fronteras, en el cual se construyó afectivamente para las madres una identidad no perteneciente y básicamente no finlandesa, al ser retratadas como "conversas" y "yihadistas". Se movilizaron emociones como la compasión, con resultados ambiguos. De una parte, la alusión a la compasión sirvió a los propósitos del programa conservador de conectar derechos con valor personal; de la otra, la alusión a la compasión por la figura del niño inocente sirvió para aislar a los hijos de sus madres. En el contexto jurídico, las identidades de las madres, construidas afectivamente como no pertenecientes, fueron importantes porque hicieron que los derechos y las obligaciones jurídicas fueran percibidos como pertenecientes a la esfera del derecho nacional o internacional.

\section{Palabras clave}

Derechos de los niños; derecho y afecto; combatientes extranjeros; Siria 


\section{Table of contents}

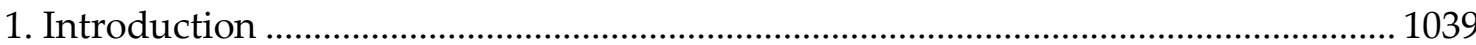

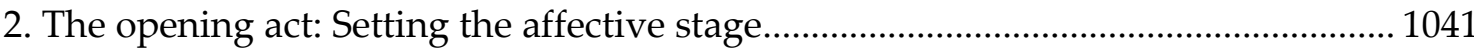

2.1. Setting the stage: interview with Sanna in March 2019.................................... 1041

2.2. Affective figures of the "convert" and the "jihadist" ........................................ 1047

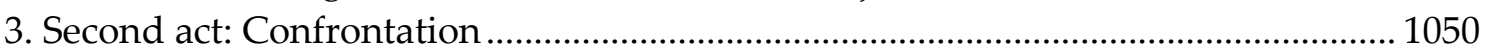

3.1. Confrontation: Political responses in the spring of 2019.................................. 1050

3.2. Bordering through affect: Belonging as the central distinction........................ 1052

4. The final act: Resolution in the form of legal responses? ......................................... 1054

4.1. "Sentiments of justice": The decision of the Chancellor of Justice

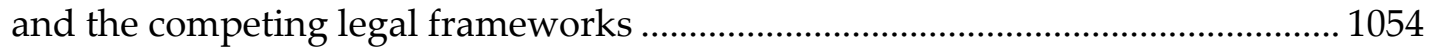

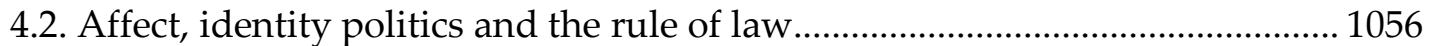

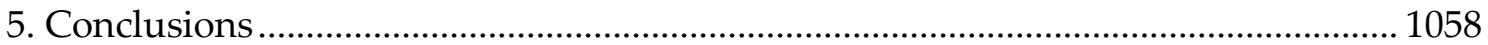

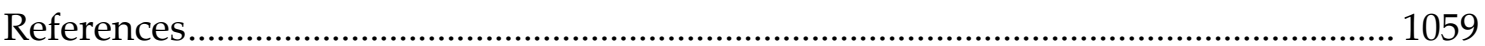

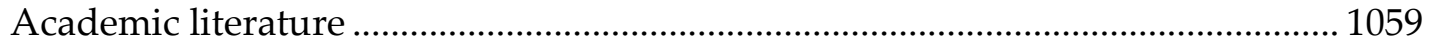

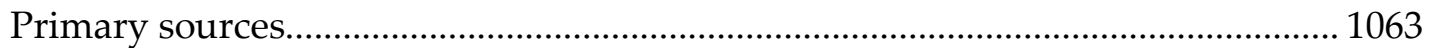

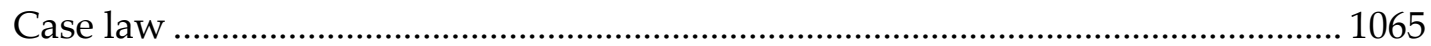


This Finnish woman came to Syria via Turkey 4 years ago. She lived in Manbij, Bab, Raqqa etc. She married twice. Her daughter is 13 now \& she's also married. Mother says they want to go to Finland because life is easier there \& they want to live as Moslems there \#Baghouz \#SDF

(Mutlu Civiroglu in Twitter on 6 March 2019)

\section{Introduction}

In March 2019, a tweet posted by journalist Mutlu Civiroglu and an interview with the American TV channel CNN made the headlines in the Finnish media and brought the Finnish "ISIS wife" Sanna and her four children to the consciousness of the general public. Sanna, her children and thousands of other "families of the caliphate" (McKernan 2019) were captured escaping Baghouz, and have since been held as captives in the camp of Al-Hol in north-east Syria, where a humanitarian catastrophe is unfolding. ${ }^{1}$ Desperate to leave the hellish conditions of the camp,,$^{2}$ the women, their relatives or NGOs and even researchers have pleaded with the governments of these women and children for help (e.g. Sillanpää 2019a, Addario 2019, Mehra 2019, Speckhard 2020). The issue of what to do with the women and their children is heatedly debated all over Europe; there seems to be willingness to take back only orphaned children (Renard and Coolsaet 2018, Mehra 2019, Coleman and Cook 2020, Mustasaari 2020). Actions and inactions of governments have been subjected to judicial reviews in several European courts, but the role of law in the public debate has remained ambiguous. ${ }^{3}$

In the UK, the Home Office revoked the British citizenship of the 19-year-old "ISIS wife" Shamima Begum. Although the decision was later overruled by the Court of Appeal, the case has highlighted the prevalence of binary constructions of gender, race, class, religion and national belonging (Farnham 2019, Labenski 2020), and prompted many of us to wonder what do stories similar to Begum's tell us about the law (e.g. Labenski 2020). This article contributes to these analyses from the Finnish perspective, and uses the analytical lens of affect and emotion to examine how rights and the legal framework surrounding the issue of repatriation of the 11 Finnish women and 33 children in Al-Hol

\footnotetext{
${ }^{1}$ ISIS is the acronym of the Islamic State in Iraq and Syria, often also referred to as ISIL (Islamic State in Iraq and the Levant). The group is also known as Daesh, which is the acronym of its full Arabic name, al-Dawla al-Islamiya fi al-Iraq wa al-Sham. The use of the name Daesh is said to delegitimize the group's claim to be an "Islamic state". The acronym ISIS is used in this article as this term has become established in the Finnish media and political debate.

235,000 of the inhabitants of Al-Hol, which is more than half, are children, who were in poor condition already upon arrival to the camp. Without access to humanitarian assistance, many of them die of severe malnutrition with complications, including diarrhoea, with subsequent dehydration, and pneumonia (International Rescue Committee 2019). As families of foreign fighters are perceived as a particularly severe security threat, they are detained in a special fenced "annex" to the camp, with extremely restricted possibilities to move from the area in order, for example, to access health services provided elsewhere in the camp. As a result, the already high child mortality rate of Al-Hol is even higher in the "annex" than elsewhere in the camp.

${ }^{3}$ In the Netherlands, the Appellate Court in The Hague overturned a lower court's judgment, according to which the State was under an obligation to assist the return of the children (Newmark 2019). In other cases such responsibility has been identified, for example by Belgian and German courts (see e.g. Staff Writer with AFP 2019) and the higher administrative court of Berlin-Brandenburg (Oberverwaltungsgericht BerlinBrandenburg, Decision 6 November 2019, ECLI:DE:OVGBEBB:2019:1106.OVG10S43.19.00).
} 
were understood, debated and problematized in the public debate during the year 2019.4 However, the details of the applicable legal rules will not be the subject of scrutiny here, as these have been addressed elsewhere (e.g. Mehra 2019, Schwander 2019, Mustasaari 2020).

In recent years, social and cultural studies have witnessed a proliferation of inquiries focusing on emotion and affect (e.g. Stearns and Stearns 1985, Reddy 2001, Gregg and Seigworth 2010, Frevert 2010, 2014a, 2014b, Scheer 2012, Ahmed 2014, Matt and Stearns 2014, Rosenwein and Cristiani 2018, Bens 2018, Bens and Zenker 2019). Without going deeper into the differences between the many approaches and ways of theorizing emotion and affect, I will briefly explain the terms as used in this article. While some distinguish feelings, emotions and affects for example following Massumi's (2002) classification, according to which feelings are personal and biographical, emotions are social, and affects are pre-personal, much of the recent theory contests such rigid distinctions (see e.g. Paasonen 2011, Ahmed 2014). In using the term "affect" in this text, I follow Paasonen $(2011,26)$, who refers to affect as intensities of experience, bodily sensations and resonances, and notes that in practice affects are impossible to distinguish from articulations of emotion. However, when referring to how affect or sensation is being named and interpreted, I use the term "emotion". In addition to these, in the final section of the article I use the term "sentiment of justice", which was coined by Bens and Zenker (2019) who wanted to conceptually connect cognitive processes of evaluating and judging with affective and emotional dynamics. "Sentiment" thus governs what people feel about the meaning of a context, which here is the context of justice and law.

The approach adopted in this article assumes as a starting point that affects and emotions are social and cultural practices, rather than merely psychological states, that produce meaning and attach value to particular bodies and individuals (Scheer 2012, Ahmed 2014). Affects also define legal contexts through spatial notions and distinctions regarding the belonging of the other's body, an operation to which Yuval-Davis, Wemyss and Cassidy (2019) refer to as "bordering".

I will, to some extent, bring to the fore my own affective reactions, as I have been following (and to some degree also participating in) the Finnish public debate. Indeed, the affective reaction - and the values such reaction reveals - no doubt directs the focus and analysis of the researcher. As Paasonen $(2011,23)$ reminds us, assuming a position of being above the studied subject prevents one from seeing the effects that being affectively moved have on interpretation. Following the central ideas of situated knowledge (Haraway 1988) and standpoint theory, objectivity should be understood as embodied, which emphasises the necessity of critical reflection about the epistemic relevance of the social location of the researcher (see e.g. Charmaz 2012, Grasswick 2018). However, defining the ways in which the identity of and affects experienced by the researcher are relevant for the analysis of affect and law is far from an easy task.

Relevant to the Finnish context, in recent years the Nordic welfare model has begun to fray at the edges, and universalist notions have been pushed aside by "the ideals of the autonomous capable citizen" (Hellman et al. 2017, 18). Simultaneously, the governing of

\footnotetext{
${ }^{4}$ Of the estimated 80 individuals who travelled from Finland to join ISIS, approximately 20 were women and 30 were children.
} 
ethnicized and racialized minority families in Finland has begun to follow three bases of logic: the normalizing family, normative (liberal) individuality, and the rhetoric of securitized borders (Keskinen 2017, see also Hiitola 2015). This article suggests a connection between the way in which the women and children in Al-Hol are depicted as undeserving of basic fundamental rights and the processes through which ethnic minority families in Finland become further ethnicized and racialized. A focus on emotion and affect might help us understand how contemporary developments bring about changes in emotional norms and the "emotional regime" (Reddy 2001) and thus shape our shared understandings of children's rights in particular and human rights more generally.

The analysis draws on material consisting of the minutes of the Plenary Debates of the Parliament, in which the issue of ISIS families was brought up; newspaper and tabloid articles, together with documentary films; and news and debate programmes produced by the Finnish public service broadcasting company YLE. The material was collected as part of a research project on transnational childhoods and related state practices in the field of child welfare. ${ }^{5}$

The debate and its analysis is depicted in three acts. The first act sets the stage by first examining the interview between Sanna and CNN's Ben Wedeman (2.1) and then examining how an affective narrative of non-belonging emerged from the interview and other media coverage and how the figures of the "convert" and the "jihadist" were affectively linked to undermine the belonging of the women and children to the Finnish "us" (2.2). The second act looks at the confrontation, i.e. the political responses (3.1) and processes of bordering (3.2) at play in the political debate. The third and final act studies law as a means towards a resolution (4.1), and examines how the affective figures and the narrative of non-belonging come to contextualise the case, both at the level of determining the proper legal context of the issue at stake and at the level of contesting the decision-making procedure (4.2).

\section{The opening act: Setting the affective stage}

\subsection{Setting the stage: interview with Sanna in March 2019}

Information about the Finnish women and children in Al-Hol began to trickle out during spring 2019. Sanna's interview with CNN's international correspondent Ben Wedeman in March 2019 was published in the Finnish media and hence brought the issue into prominence amongst the general Finnish public. In the news reports of both local and global media, we learned more about the "wives and children of ISIS" (Chulov and McKernan 2019) who were "warehoused in Syria, unwanted back home" (Hubbard 2019), as well as about the humanitarian catastrophe at the camp: the overcrowding, poor hygiene, desperately insufficient supplies of water and basic food supplies (Doctors Without Borders 2019). Unprotected against extremes in temperature, the inhabitants of the camp were exposed to heat in the summer and cold in the winter, as well as to water

\footnotetext{
${ }^{5}$ The research project is entitled Children Abroad: A Relational Analysis of Finnish Child Protection and Welfare in Transnational Contexts [CARELA]. It is located at the University of Eastern Finland Law School and funded by the Academy of Finland.
} 
flooding into their tents. They are also under a continuous threat of severe violence (Speckhard 2020).

As an opening act to the Finnish public debate over the women and children in Al-Hol, Sanna's interview by Wedeman sets up the affective context over the rights to return and to state assistance. In the interview Sanna is dressed in a black niqab, Islamic dress that several European states have banned as a symbol of violent extremism and failed integration. ${ }^{6}$ The camera focuses on her eyes.

Wedeman: Suomi? [Finland?]

Sanna: Yes. Suomi.

Wedeman: Why are you here? [She hesitates]. Very simple question. You are in Syria. You are from Suomi. Why are you here?

Sanna: We came here four years ago.

Wedeman: Why?

Sanna: To live in Sham. Islam... Islam country.

Wedeman: And where is your husband?

Sanna: Dead.

Wedeman: And how did he die?

Sanna: In a car accident.

Wedeman: Really? And what did he do here?

Sanna: He was plumber. He... It was long time ago... Before Bashar was destroying things.

Wedeman: Was he originally Syrian?

Sanna: No, Moroccan.

Wedeman: And you are Finnish? I mean, Suomi, Suomi?

Sanna: Suomi, kyllä. [Finnish, yes].

Wedeman: And you still believe in the Islamic State? The al-Dawla al-Islamiya?

Sanna: No. [Shakes her head]. I believe in Islam. I want to live in Islamist way, like Islamic way. But this is... [Shakes her head]. This is something horrible now.

Wedeman: So tell me, what do you mean, was the Dawla horrible? I'm not... Islam is something, but was Dawla... something else?

Sanna: Yeah, yeah... No. In Syria was nice, when I came, in the beginning. It was nice. And everything works, schools and everything, food and houses and... Like normal life. But then it changed. Horrible bombing and war. I didn't want to be in the war.

Wedeman: So the problem was not with the Dawla, the Islamic state? The problem was with the war?

Sanna: Yeah, yeah.

\footnotetext{
${ }^{6}$ The interview by the CNN reporter Ben Wedeman presumably took place on 5 March 2019 and was published shortly afterwards by the Finnish tabloid newspaper Ilta-Sanomat (7 March 2019). The 8-minute long video can be accessed here: https://www.is.fi/ulkomaat/art-2000006026121.html
} 
Wedeman: From the American, and the French and the British... but didn't you know what the Dawla was doing? In terms of their taking pictures of people having their heads cut off? And making the Yezidi women into slaves? And...

Sanna: Yes, I've seen that in the media, yeah, yeah.

Wedeman: And you don't, didn't have a problem with that?

Sanna: No, it's different. There's stories. I didn't believe them.

Wedeman: But they're true.

Sanna: But I don't really believe...

Wedeman: I have friends who had their heads cut off. I know them, I saw them on television.

Sanna: Oh. [She looks down].

Wedeman: They have lost their heads.

Sanna: Ok.

Wedeman: And that's ok with you? If Sharia says go ahead and cut off the head, then that's ok?

Sanna: Well, Sharia is Sharia. Then... I believe Sharia. Like, when it's in Quran, then it's fine. But then, if it is without court, then... Like when it's without... how do you say it... trial, then no.

The conversation continues on the theme of the horrors that ISIS perpetrated, the 2015 Paris attack and the role of ISIS in the attack. Wedeman continues to press for an answer to whether she thinks that the attacks were justified. At this point the camera zooms out, revealing the wider surroundings. Sanna is sitting on a rug spread out on sandy soil, with two small children sitting with her. Some other people seem to share the rug with Sanna and her children, and further away we can see similar groups sitting on rugs in the desert. The children sit quietly, their faces are blurred in the video to prevent them from being recognisable, and their heads seem to be covered. As Wedeman continues to describe the violent acts of ISIS, a smaller child suddenly interrupts, saying "äiti" in clear Finnish ("mother"), to which Sanna replies "odota nytten siinä" ("just wait there"). The conversation then moves to her religious views and Islam.

Wedeman: Did you convert to Islam or have you always been a Muslim?

Sanna: No, converted. I was Christian.

Wedeman: How many years ago did you convert?

Sanna: 14 .

Wedeman: What is your name?

Sanna: Sanna.

Wedeman: What is your last name?

Sanna: No, just Sanna. From Finland.

Wedeman: And tell me about the situation in Baghouz before you left. Were you living in a tent, or underground, in tunnels?

Sanna: In the tent. 
[The voice of a child interrupts in Finnish: 'Äiti, toi haluu...' ('Mum, X wants...')].

Wedeman: Tell me how did you live?

[The child interrupts again: 'Se haluu toisen, toi...' ('X wants another one...')]

Wedeman: Because we saw, we saw bomb, bomb, bomb... [He gestures mimicking bombs coming from the sky].

Sanna: That was the horrible... I didn't want... I wanted to go out long time ago, two years ago. But then I was afraid...

[The child interrupts again, tries to address Sanna in different ways. They seem to be eating something from a yellow tin can].

Sanna: Like what would happen if we go out. I wanted to go out, I couldn't. I was afraid that they will torture my children, torture me. So we couldn't go, we just continued our life.

Wedeman: So you were afraid... Who would have tortured your children?

Sanna: Like, these camps... I don't know is it PPK now, or who is taking care of the camps.

Wedeman: It's the United Nations.

Sanna: Yeah, that was that, the rumours were so bad. I was like, we have food, we have like normal life, let's continue. But for a long time I was... [gestures desperately].

Wedeman: From three years... But where did you live when in the Dawla. Mosul, Raqqa...?

Sanna. In Manjib. That was so nice.

Wedeman: And have you been in contact with your family in Finland?

Sanna: Yeah, all the time. They know I am, we are here.

Wedeman: And everybody in Finland, the Government knows you're here.

Sanna: Yeah, they must...

Wedeman: Do they... Do you want to go back to Finland?

Sanna: No, they didn't ask.

Wedeman: But do you want to go?

Sanna: I did, but then I was afraid.

[An older child, whom we later learn is Sanna's 13-year-old daughter, intervenes in the conversation, asking Sanna in English: 'Do you want to go back to Finland?' Sanna is confused, she answers in Finnish: 'Ai niinku nyt hetikö?' ('You mean like right now?')].

Sanna: Yes, yes, I want to go back to Finland! Definitely, definitely, definitely, definitely!

Wedeman: Even though Finland is not al-Dawla al-Islamiya?

Sanna: But I can be Muslim there. Finland is easy to live in.

Wedeman: But if Finland is easy for you to be a Muslim, why did you come here?

Sanna: Because the Prophet said that Sham is a good place to live. That's why I came.

Wedeman: And did you not know about... Did you know any Yezidi women, the ones they sold in the market as slaves? 
Sanna: No. Never seen them, never heard.

Then Wedeman addresses Sanna's daughter Sumeya. One would assume that these people must be severely traumatized. Yet Wedeman continues to probe whether she will continue to wear the niqab and whether she will attend school in Finland, if the Finnish Government fetches them home.

Wedeman: And were you happy living in Dawla?

Sumeya: It's normal, um.

Wedeman: It's normal? Even though there's bombs and... Do you speak Arabic?

Sumeya: Yes, I learned already in Finland Arabic.

Wedeman: So how old are you?

Sumeya: 13.

Wedeman: And do you want to go back to Finland?

Sumeya: Yes.

Wedeman: And when you go back to Finland do you want to live just like a normal person? Do you want to take this off [he points at the veil and inhales theatrically] and have some fresh air?

Sumeya: No, I want to be with this.

Wedeman: So you want to go back to school in Finland and see normal Finnish children like you?

[The camera moves from Sumeya's face, covered with the full black veil, and zooms in on her hands, as she fiddles with something nervously].

Sumeya: I would like to be at home, in the school at home.

Wedeman: Not with other Finnish children.

Sumeya: No...

Wedeman: My wife's mother is from Helsinki. She says the best schools in the world are in Finland. The best education. Did you go to school in Dawla?

Sumeya: Yes, um, one time I went...

Wedeman: But in the last three days, in Baghouz, for instance not yesterday but the day before yesterday, there was much bombings. Did they hit the tents? Were there many women and children killed?

Sanna: Yes. We were almost burned in the tent.

Wedeman: Really? At night or in the daytime?

Sanna: Day time.

Wedeman: The day before yesterday?

Sanna: Yes... No. Three days ago. Everything burned. We don't have... we have this what we have [points to her garment and the few belongings on the rug]. Or actually we got something from others... But everything burned.

Wedeman: Sounds very difficult.

Sanna: That was, like long time ago it was not normal life. 
The interview is over. Located there, in the middle of the desert, the video indeed shows, in very concrete terms, how they had lost everything: the tent in which they lived in the middle of the war, the few belongings they had with which to survive there. And the dream of Sham, the true Islamic society, the safe haven, utopia, they had left Finland for. Sanna, a mother with her young children, for whom everything had gone so terribly wrong. The two small children eating from a yellow tin can, with nowhere to go. And Sumeya, a 13-year-old girl, who, as we learned from Civiroglu's tweet and later from another interview, had married a fighter just a little before they left Baghouz (Kuronen 2019a).

The scene is both utterly strange and immediately familiar: the child interrupting, just like mine would, weary of waiting for their turn, bored at the conversations of the grown-ups. If, to begin with, the "child-body is the quintessential site of moral compassion" (van Wichelen 2015), hearing the child address its mother in Finnish in a refugee camp somewhat emphasizes the effect. Finnish is a language one hardly ever hears in international news, and the language itself is a powerful signal of belonging to the Finnish "us". After watching the interview clip, I find myself baffled and desperate, thinking about how hungry they must be out there, so exposed and vulnerable. "Thank God we can rely on the rule of law and the welfare state, surely these people will be helped", I think to myself - a feeling of confidence that now in retrospect seems utterly naïve.

My affective response is, of course, socially anchored. As a mother of children who are apparently of the same age group as Sanna's and who call me "äiti" (indeed, hundreds of times during the writing of this article), I am of course attuned to feelings of anxiety and horror in the face of children's suffering. And as a lawyer, I have been shocked to see how little weight has been given to the rights and lives of children in the public debate. Although these affective reactions no doubt directed my attention and motivated further research, it is important to bear in mind that a standpoint does not merely automatically arise from a particular social location or aspect of identity (Grasswick 2018). Constructing a standpoint, and including one's own affects within it, requires a more profound reflection and the recognition of the historicity of affect. Although such profound reflection can hardly be made in the limited space of this article, I will return to this issue briefly in the concluding section. Here, however, I want to highlight the social nature of affect and emotion.

Scheer $(2012,200)$ emphasizes that emotions are not only automatic or "inner", but depend on socialisation, "a learned, culturally specific, and habitual distribution of attention to 'inner' processes of thought, feeling, and perception", which are not universal traits of personality or subjectivity. In order to foster an appropriate emotional response, I must be able to identify those that are to be cared for. Compassion, for example, thrusts me towards the suffering other - depending on how I perceive the other (higher or lower in rank than myself; like or unlike myself; victim or perpetrator, etc.). The body of the child is almost immediately, unquestionably identifiable as a body to be cared for. Knowing how they suffer, hearing cries for "äiti" (in English, "mother") in our heads - how could we decide not to take all possible measures to bring home the children from the desert? How could we not help Sumeya, knowing she is a victim of child marriage and will probably marry again, if the camp collapses? 
Writing about how the image of the dead body of the three-year-old Aylan Kurdi, who was washed ashore in Turkey in 2015, had the power to make the European public question the morality of immigration laws, Gozdecka (in press) reminds us that in order to invoke an ethical response - a sense of responsibility - the suffering body needs to be able to cross the threshold of anonymity and to be affectively understood as one of us. This threshold was crossed by the Finnish women and children at Al-Hol due to their attachments to a Finnish "us". This belonging, however, was effectively contested by invoking an "othering" narrative in which these attachments were undermined. What became central in the political debate was the struggle over the proper response to the suffering of the children and their mothers in Al-Hol. This was essentially an issue of orienting the affective response correctly, to use Ahmed's words, in this newly opened space for "affective forms of reorientation" (Ahmed 2014, 8).

\subsection{Affective figures of the "convert" and the "jihadist"}

The themes that Wedeman persistently pursues during the eight-minute-long clip of the interview include the crimes of ISIS, Sanna and Sumeya's religious views and (in)fidelity to the Finnish state. At times, the tone of the interview is bluntly disrespectful. In fact, the interaction resembled more an interrogation than an interview, with its emphasis far from the current situation of the family, or how they manage, or the mental or medical condition of the children. Wedeman wanted them to clearly indicate whether they condemn ISIS, and whether their religious views still remain unchanged, even though publicly expressing anti-ISIS views can prove lethal (International Center for the Study of Violent Extremism 2019, Speckhard 2020,2). We can hear the flash of hope in Sumeya's voice when the issue of return to Finland is brought up and as she asks her mother repeatedly, in a heated voice, if she wants to go back to Finland. The hope is quickly displaced by confusion and distress, as Wedeman continues to probe about her willingness to "live like a normal person", go back to a Finnish school and stop wearing the niqab.

In the media coverage following CNN's interview, the backgrounds of the Finnish women in Al-Hol quickly became the central focus of attention (Sillanpää 2019a, Kuronen 2019a, 2019b). The media published messages they had sent from the camp as well as their earlier posts in social media. They were interviewed together and separately on several occasions (e.g. Kuronen 2019b). From the countless reports and articles we learned that amongst the women, two groups were over-represented, the ethnically Finnish converts and Finnish Somalis (Kuronen 2019b, Sillanpää 2019a). The previous role of some of the women in radicalized groups and their alleged participation in spreading propaganda material was brought to the public consciousness, as were their personal ties and membership in jihadist networks (e.g. Sillanpää 2019a).

From Wedeman's interview and the subsequent media coverage, a powerful narrative emerged to contest the belonging of the individuals to the Finnish "us". This narrative centred around two mutually constitutive figures, the figure of the "convert" and the figure of the "jihadist". Narratives represent cultural understandings of how a particular situation should be made sense of and are thus central to processes of meaning-making and signification, which are always socially and culturally produced and situated (Fulton 2005). Through a narrative, elements of the story are linked to compose relations of significance, and thus the narrative always comprises an element of evaluation 
(Hoffmann 2010, Phoenix 2013). As Phoenix (2013) points out, particular ways of telling the story bring into being identities or reproduce them. As we shall see in the next section, the affective construction of the narrative of the women's non-belonging also had important ramifications to how the legal framework came to be perceived.

Using the figure of the convert in the narrative of the non-belonging of the women served to construct a clear border between the ethnically Finnish Muslim women and "genuinely" Finnish people; seeds of suspicion about the belonging of the women to the Finnish "us" were sown the very moment the issue of converting to Islam was brought up in the interview. The fact that they had converted to Islam came to signal not merely their religious views but also their abandonment of Finnishness, the voluntariness of their opting out and non-belonging to the Finnish society. It makes little sense to ask a child fleeing war about how she will dress if repatriated to Finland - unless the purpose is to inquire about her assumed non-belonging to the Finnish society.

Research on ethnically European converts to Islam demonstrates that European mainstream societies marginalize converts, treat them with suspicion and question their belonging to these societies (e.g. van Nieuwkerk 2004, Jensen 2008, Galonnier 2015, Özyürek 2015, Moors and Vroon-Najem 2019). As for example Moors and Vroon-Najem (2019, 22-23) explain, "becoming recognizably Muslim, particularly through wearing a headscarf, puts their self-evident belonging to the nation into question and turns them into symbolic migrants". Galonnier $(2015,572,575)$ notes that while the white converts to Islam challenge the association between Islam and foreignness, in the context of the "war on terror", there is also a tendency to racialize them through the figure of the "Muslim terrorist", which identifies a racial boundary between "us", the West, and "them", the terrorists (see also Puar and Rai 2002; Kumar 2015). Not surprisingly then, the conversion of an ethnically Finnish Christian woman was eagerly associated with religious radicalisation. Of course, such association depicts a far too simplistic view of why some converts may find religious fundamentalism appealing (and even of those who do, only a small percentage would support violent extremism).

The figure of the "convert" was associated with the horrendous figure of the jihadi terrorist central to the "Europe at war"-narrative, in which "us", the Europeans or the Westerners, are pitted against the inhuman enemy that threatens "the symbolic kinship of the nation, religion and humanity" (Miller 2018). In the claim that the Finnish women belong to the enemy and not to Finnish society, affects play a central role through their ability to determine the relationship between seemingly unrelated "signs", i.e. images, words, phrases or bodies (Ahmed 2014, 194). ${ }^{7}$ Ahmed $(2014,76)$ points out that when signs become closely associated, their meanings become intertwined in an unarticulated manner, and such associations actually "stick precisely insofar as they resist literalisation". When the association with a sign becomes intrinsic, it becomes a form of signing and generates meaning.

The figures of the jihadist and the convert mutually constitute and inform one another, thus shaping the narrative of the non-belonging and foreignness of the women. For example, by pushing for answers from the 13-year-old refugee girl Sumeya about her

\footnotetext{
7 A "sign" refers here to poststructuralist understanding of language, which draws on, with significant modifications, Saussure's structural linguistics (see, for example, St.Pierre 2000).
} 
willingness to take off her niqab and start behaving "normally", Wedeman contributed to both appropriating the meaning of the niqab and linking the figure of the "convert" to the enemy figure of the "jihadist". The importance of such circulation and movement between signs is that this movement allows signs to increase in affective intensity; "the more signs circulate, the more affective they become" (Ahmed 2014, 45).

On the one hand, signs become saturated with affect, and on the other hand, emotions align some bodies with others, sticking some figures together (Ahmed 2014, 194). This work of "affective economy" enables us to fill up the object of the emotion with that emotion, which then "becomes a sign of the "truth" of the reading" (Ahmed 2014, 52). The affective economy of fear, terror, and war presents anyone who is associated with foreign fighters and who cannot claim complete innocence or lack of agency as deviant, other and non-deserving. This also contributes to the fragmentation of the child subject. From the abused, vulnerable refugee girl, there emerged a transgressive, non-Finnish subject. As we shall see, this "new" subject was readily adopted in the political debates in utterances that would provide rights only to the very small children.

Affects and emotions both generate their objects and reiterate past associations. Today's debates about ISIS women and their children are rooted in the histories of these women's countries of origin. From the Finnish perspective, a particularly interesting period of history is that of the aftermath of the Civil War of 1918, described as one of the bloodiest civil wars on the European continent, fought between the Reds (led by radical socialist movements) and the Whites (led by the conservative-based Senate and German troops). After the war, the debate was heated about what to do with "the devil's bastards", the children of the Reds who lost the war (Kaarninen 2008). As noted by historians, the resemblances between the debates of 1919 and 2019 are striking (Koskinen 2019).

The class divisions and tensions leading to the Civil War of 1918 were suppressed but did not vanish during the decades of rebuilding and constructing of the welfare state, although the state gradually became accepted as the central agent of solidarity (Hellman et al. 2017). On an affective level, the trauma of the Civil War continued to divide Finns. This is also relevant from the perspective of social locations and positionality. Coming from a working-class background, I find it easy to understand that there are reasons why the dominant social structure might not seem appealing to everyone. In the 1930s, my grandmother left her home at the age of 12 and moved to a distant household to serve as a home help. Four years later she had her first child, and much later she married my grandfather, a devoted communist and supporter of the Reds. Due to my family history, I have grown up in an affective atmosphere of empathy and feelings of injustice regarding the cruelties faced by the Reds and their offspring. While the exact relevance of such histories to the research and analysis remains an open question, they do call for reflection, especially since the polarized political climate of today once again emphasises divisions between the supporters of the populist right and those (like myself) who see the populist rightist movements as a clear threat to the universalism and founding principles of the welfare state and the solidarity it represents.

Similar to the dynamics in 1919, the two interlinked figures of the convert and the jihadist served to strengthen the narrative of the women as enemies and non-belonging through simplifying what in reality was complex (see for example Orozobekova, forthcoming, 2021); the women, whose situations, levels of agency and reasons for 
traveling to the area differed considerably, were equated and treated as one. As the women were seen as not only merely potential perpetrators, criminals or incapable parents but as representatives of utmost evil, the affective response of compassion towards the suffering children was overridden and reoriented by fear, anger, hate and feelings of betrayal towards their mothers. These affects were efficiently taken up in the second act of our story, the political debates conducted during spring 2019.

\section{Second act: Confrontation}

\subsection{Confrontation: Political responses in the spring of 2019}

Following the media attention that Sanna's interviews received, the issue of "ISIS families" was brought up at Question Time of a Plenary session of Parliament. Many speakers, for example the Christian Democrat MPs, emphasized the security threat posed by the people affiliated with ISIS, and demanded state action in order to prevent the fighters and their wives from returning. Ministers of the centre-right Government, such as Antti Häkkänen, the then-minister of justice and a lawyer by training, referred to the "broad consensus in Europe" that these people should not be allowed to return. The then-minister of the interior Kai Mykkänen stated on several occasions that Finland will not assist the return of any individuals from Al-Hol and that Finland was looking into the possibility of depriving them of their Finnish citizenship.

With both domestic and European parliamentary elections just around the corner, much was at stake politically. The right-wing populists, who enjoyed a considerable broad support and were predicted to do well in the elections, were spreading a rather harsh ethno-nationalist, anti-immigration and anti-European message. As always, the elections were defined by identity politics, attempts to appeal to identities in order to form political alliances. In this situation, the political risks involved in voicing the constitutional rights of families allegedly associated with Jihadism were understandably high.

The Finnish Parliamentary elections on 14 April 2019 resulted in a razor-thin victory for the Social Democratic Party over the second-ranked Finns Party, the Finnish member of the Populist Radical Right party family. The process of forming a new government was not easy, and the elections to the European Parliament in May 2019 increased tensions even further. When the "great Euro election debate" of the party leaders was aired on 23 May, the negotiations about the formation of a governing coalition were still on-going.

The debate opened with the question of what actions the Government should take regarding the women and children held in Al-Hol. Most of the participants denied having exact knowledge of the situation, and many supported the idea that an international ad hoc court be established in Syria to investigate and prosecute individuals in the camp itself. Juha Sipilä, the then-prime minister highlighted that adults who have made the decision to join ISIS would not be welcomed either "joyfully or with open arms" (my translation). When it comes to children, according to Sipilä, the "question is far more complicated" (my translation).

The chairperson of the National Coalition Party, Petteri Orpo, emphasised the connection between compassion and worthiness: 
I do not feel, and nobody should feel, any compassion towards the adults in the camp. They have chosen themselves to join the brutal terrorist organization and we have no reason to help them. But if there are very small children, who have not in any way been capable of affecting whether or not they will be taken to the camp, then it is a matter for serious consideration. (Orpo, my translation)

Pekka Haavisto, the chairperson of the Greens, pointed out that humanitarian help should be directed to the camp and that children should be rescued from the camp. The chairperson of the Left Alliance, Li Andersson, also stated that children need to be helped and was the only person in the debate to consider whether, in the event that the process of establishing the ad hoc tribunal would take too long, it would be possible to bring the individuals to Finland and initiate criminal proceedings there.

Jussi Halla-aho, the chairperson of the ethno-nationalist Finns Party, expressed pity towards the children but described their mothers as a threat to the state:

They left voluntarily to join their Islamic paradise. They are walking time-bombs if they come back here. Children are of course to be pitied, because they cannot choose their parents, but it is absolutely in the national interest that these women are not taken back to this country. (Halla-aho, my translation)

Anna-Maja Henriksson, the chairperson of the Swedish party, ${ }^{8}$ expressed her support for the Swedish initiative to establish the international tribunal and agreed with Hallaaho and the Finns Party that in practice it would be difficult to investigate the participation of the individuals in war crimes but stated that in her opinion the process would be more efficient in the international tribunal than if these people were brought home. She continued by affirming that "children always have, according to international law, children's rights that are independent of where they are. They need to be helped".

Sari Essayah, chairperson of the Christian Democrats, insisted that irrespective of whether the women had been cooking or fighting, they had been involved and they need to be investigated either in Syria or the Middle East. According to Essayah, the children needed to be helped, but the adults were a grave security risk.

In the debate, articulating affect and naming emotions was central in the discursive production of the legitimate and just response of the state. Expressions that labelled the women - as well as any children who are not "very young" - as perpetrators or terrorists or security threats effectively mobilized fear and resentment in the audience. For example, through associating cooking with fighting, fear and anger was also mobilized in relation to whatever might be seen as ordinary in the lives of these women; even the ordinary becomes terrorist activity, a source of fear and hate. While it is true that only in the populist rhetoric were the women and children in Al-Hol openly referred to as "walking time-bombs", the emotional practice of mobilizing fear and resentment was a joint effort; while milder in expression, the utterances of other party leaders supported rather than contested this practice.

What emerged as central in the debate were the affective techniques of constructing and reproducing the border between "us" and "them", in terms of both territorial border and

\footnotetext{
${ }^{8}$ The Swedish People's Party of Finland is a liberal-centrist political party that represents the interests of the minority Swedish-speaking population of Finland. Despite being a small party, it has been nearly continuously in the government since 1956.
} 
politically defined belonging. Whilst all the talk was about compassion, the emotions effectively signalled were resentment, anger and hate - the naming of the emotion had the effect of converting hate and resentment into expressions of love and care. This allowed the speakers to associate themselves with "good feeling" and "positive value" and present themselves as people concerned with the well-being of others (Ahmed 2014, 123). The way in which emotions were named, for example as compassion or pity, served to signal which responses were to be felt natural, proper or possible (Scheer 2012). Naming and interpretation of affects brought the conceptual frameworks and hierarchies into the picture.

Both pity and compassion have the potential to invoke associations with responsibility, but not necessarily in a binding sense. Pity and compassion were used to signal charity and "a position of power over others" (Ahmed 2014, 22). Consequently, the question of justice became a question of compassion and "good will", elevating the speaker above the people whose right to life is at stake. Furthermore, by adopting and reiterating the narrative of the families' non-belonging and non-Finnishness, the speakers were able to locate the applicable legal framework into the realm of international law rather than national law. Simultaneously, the affectively constructed foreign and dangerous subjects central to this narrative allowed the speakers to redefine the subject of the rights of the child so that in fact these rights would only be provided to very small children.

\subsection{Bordering through affect: Belonging as the central distinction}

The narrative of the families' non-belonging and non-Finnishness was explicitly adopted in the immediate responses voiced by politicians during spring 2019. Utterances emphasising the "European" or "Nordic" consensus were designed to legitimate harsh policies, but also to appeal to the Finnish "us", who as Europeans and as members of the Nordic countries' citizenry stood in one front in the war against terrorism. As the first option of dealing with the problem, the deprivation of citizenship, had turned out to be all too clearly illegal and thus utterly unfeasible, the process of boundary-making or bordering, to use the term of Yuval-Davis, Wemyss and Cassidy (2019), had to take other forms.

Yuval-Davis, Wemyss and Cassidy $(2019,24)$ argue that "[b]ordering constitutes a principal organising mechanism in constructing, maintaining, and controlling social and political order". One ramification of the contemporary centrality of bordering processes is manifested in the rapid rise of the populist radical right (Jungar and Jupskås 2014, Nordensvard and Ketola 2015). Members of this cluster share in common an authoritarian position on sociocultural issues, exclusionary and ethnically based nationalism, which emphasizes the need to stay as homogeneous as possible, law-andorder policies, and a value-base that stresses pro-military and traditional family values (Jungar and Jupskås 2014, 218). Their policies focus on framing social and economic rights based on the logic of cultural and ethnic belonging (Nordensvard and Ketola 2015, 371.)

With the general weakening of universalist notions of welfare, the populist radical right is no longer alone in making welfare nationalistic or chauvinistic arguments. Drawing on an analysis of the immigration programmes of Finnish political parties, and the parliamentary debates and policy documents that map the changing asylum policies in 
the period 2009-2011, Keskinen shows how the egalitarian principles of the welfare state "can be bent when agreements are made between right-wing populists and other parties" (Keskinen 2016, 366). She notes that ultimately the struggle over entitlement to welfare services is about definitions of belonging. Similarly, the emerging lines that demarcate the citizen subject of the welfare state also came to constitute the crucial question in the debate over the rights of women and children in Al-Hol.

Belonging is affective precisely because it escapes fixed definitions; it is experienced and recognized (as well as mis-recognized) on an affective, experiential level (Yuval-Davis 2011, Mustasaari 2017). The belonging of a Finnish-speaking child in the Finnish "us" is intuitive, but in the context of the war on terror it becomes exclusionary and easily disturbed by the imagery of otherness, such as the niqab, utterances that embrace the Islamic way of life, or imagery of the refugee camp. The "affective forms of reorientation" (Ahmed 2014, 8) are socially significant, because they are part of social and cultural practices. This brings not only social norms but also history into the picture, as the process through which certain structures become meaningful and felt as natural and ordinary is historical (Frevert 2010, Ahmed 2014, 56). At the same time as the speakers communicated exclusion and punishment, they also wanted to appear true to the ethical demands raised by the "suffering child", due to the centrality of the political category of the child. Of course, both were not possible.

Presenting the women as an extremely grave security concern and utterly unworthy of state protection was necessary in order to legitimize the consequence of sacrificing the children. Similarly, utterances that granted compassion and help only to very small children introduced fracturing divisions within childhood that signaled the emergence of a new, emotional figure of the transgressive child. Reorienting affect is crucial in how some - but only some - bodies are identified as those that we can, indeed must, love and care about (Ahmed 2014, 191), and here the affective reorientation served to convince the public that leaving the children in the camp could not be avoided. Sacrificing the children of course raises the question of why the 11 identifiable women are considered such a grave security threat that they and their children must be left to die - a consequence that is clearly disproportionate, following on from a concern that looks decidedly exaggerated (The Soufan Group 2019).

In order to answer this question, it should be borne in mind that security is not only about responding to rational calculations of risks, about "securing a border that already exists" (Ahmed 2014, 76). Rather, it requires a less stable, less secure object. As feminist interventions in security studies have demonstrated, identity and security are thoroughly intertwined (Wibben 2011). Versions of security are multiple, and "the security of some is deeply implicated in, and even predicated upon, insecurity for others" (Wibben 2011, 91). As Bruce-Jones (2016) points out, racism as a set of ideologies comes with a context, which gives racism its coherence. In the context of violent Islamism, a racial boundary is constructed between "us" and "the enemy". The black minorities in Finland face racism frequently (Rastas 2012, Open Society Foundations 2013), and the affective association of the figures of "convert and "jihadist" racialized also the ethnically Finnish women. 


\section{The final act: Resolution in the form of legal responses?}

\section{1. "Sentiments of justice": The decision of the Chancellor of Justice and the} competing legal frameworks

In the third act now at hand, the issue of what the state should do about the women and children in Al-Hol assumed a legal resolution with a decision issued by the Chancellor of Justice and following action taken by the ministry of foreign affairs. The discourses, both political and legal, concerning these individuals and the appropriate state response assumed concrete and practical applications in the form of legal conceptualisation. Several legal contexts, through which the issue of state responsibility could be articulated in the form of legal obligations, emerged in the debate, including child welfare and protection, rights of the child, consular law, criminal law, international criminal law, and international humanitarian law.

In the political debate, law was invoked as a neutral and rational perspective from which the issue of repatriation could be resolved. For example, an opinion piece, signed by 15 law professors and published in the largest Finnish newspaper Helsingin Sanomat (20 June 2019), argued that the state was under a clear legal obligation to assist the citizens' return. Experts in the rights of the child, such as Inka Hetemäki from Unicef Finland and Elina Pekkarinen, the Children's Ombudsman, called for the state to save the children, arguing that the children were not to be blamed for their parents' decisions. In July 2019, the President of the Republic, Sauli Niinistö, also commented on the case, stating that the issue was extremely difficult, but that "everybody surely agrees that the children should not suffer". The suffering of the children thus became the foundation to which affective response was officially attached.

On 9 October 2019, the Chancellor of Justice Tuomas Pöysti delivered his decision on the complaints made by several different actors concerning the situation of the women and children in Al-Hol. ${ }^{9}$ According to Pöysti, the Government and the ministers had acted lawfully in the matter. The Chancellor's legal opinion was, however, that the fundamental and human rights of the individuals in the camp, in particular the right to life guaranteed by the Constitution and the Convention on the Rights of the Child, the primacy of the best interests of the child and the constitutional obligation to secure the human rights of the individuals, all served to support the conclusion that at least the children should be repatriated, and that the Finnish authorities should take measures towards that end, within the limits of their competence. However, according to the Chancellor of Justice, the legal assessment was of limited significance, since the actual possibilities of the authorities to act outside Finland are much weaker than those of acting within Finland. Furthermore, the Chancellor of Justice noted that the authorities have a broad area of discretion as to which actions are possible and emphasized that it was not within his powers or duties to order the authorities to take any specific action.

Invoking law in the debates eventually managed to legitimize the starting point that the children had some rights vis-à-vis the state. Simultaneously, however, the state was

9 The Chancellor of Justice, Decision 9 October 2019, Dnro OKV/998/1/2019, OKV/1082/1/2019, OKV/1089/1/2019, OKV/1104/1/2019, OKV/1109/1/2019, OKV/1131/1/2019, OKV/1132/1/2019, OKV/1134/1/2019， OKV/1171/1/2019， OKV/1186/1/2019， OKV/1256/1/2019， OKV/1257/1/2019， 
explicitly invested with a broad margin of discretion as to how to proceed and what actions to take. In political and legal discourse, the issue of the Finnish families in AlHol became one about how to make sense of the situation in legal terms, and to which legal framework the case should be situated. By the time when the Chancellor of Justice had issued his decision, the situation in Syria had changed again, as Turkey had begun a massive military operation against the Kurds in the northern region of Syria, immediately after the United States had announced the withdrawal of its troops from the area, leaving the Syrian Democratic Forces (SDF) without military support. Since the invasion, the security situation in the camp grew worse and providing humanitarian assistance became more difficult.

The struggle over how a particular case should be understood and localized within one of the available legal contexts is related to particular patterns and evaluative regimes of meaning that Bens and Zenker (2019) call sentiments. The concept of sentiment is central to the normative dimension of affective and emotional dynamics and thus to the reproduction of normative orders (Bens and Zenker 2019, 100). The different legal contexts have different justificatory principles, different sentiments of justice (Bens 2018, Bens and Zenker 2019). For example, Bens (2018) points out that the branch of law called transitional justice, which deals with mass atrocities, is underpinned by two partly incompatible sentiments of justice: one that focuses on the punishment of perpetrators in order to come to terms with large scale violence (retributive justice), and the other that focuses on repairing the damages caused by such violence (restorative justice).

In this case, the competing sentiments of justice as materialized in the appropriate legal field were, on the one hand, those of child welfare and rights of the child, consular law, and criminal law and, on the other hand, those of international criminal law, transitional justice and humanitarian law. While the realms of child welfare and criminal law require and bring about a jurisdiction and direct obligations to act in relation to the vulnerable individuals within this jurisdiction, the realms of international criminal law, transitional justice and humanitarian law bring about less direct obligations that are not directed to specific individuals. Thus, the critical dividing line was whether the individuals at stake could successfully claim to belong to the jurisdiction of the state in ways that would trigger direct obligations on the part of the state. Simultaneously this was an issue of whether the case was to be perceived as belonging to the realm of national law or international law.

The central sentiment of justice relating to the suffering child jeopardized by her parents would normally invoke the legal context of child welfare. In this area of law, the evaluative regime focuses on securing the rights and well-being of the child. The practices of child protection are directed at providing the most efficient services to protect the child at risk, whereas the criminal liability of the mother would here play only a limited role. Similarly, the sentiment of justice underpinning criminal law, with an emphasis on rule-of-law manifested in principles such as in dubio pro reo (a defendant may not be convicted by the court when doubts about his or her guilt remain) and nulla poena sine lege (no punishment without a law), fits poorly with the idea of refusing help and abandoning the women and children to wait for a possible trial to take place, possibly sometime in the future. 
The processes of affective signification, central to the bordering at play in the narrative about the women's non-belonging, equate "converts" and "jihadists" and assign the responsibility for the violence of ISIS collectively to the individuals in the Al-Hol camp. Hence, the suffering of the Finnish women and children in the camp was transformed from a concern of Finnish child welfare and the rights of the child into one about the punishability of the alleged war crimes of the mothers. The issue of whether or not the state should actively seek to help the individuals in Al-Hol was framed as a question of whether or not the women deserve help, partly due to their past actions and partly due to the risks they were perceived to represent in the future. This served to detach the individuals from the jurisdiction of the state and move the legal issue at hand to the realm of international law as being about more unspecific rights of the child, transitional justice and, finally, humanitarian law. What proved crucial for the children was whether or not they could be considered to belong to the Finnish "us" enough for the state to have the mandate and the responsibility to prioritize their rights to life over the security concerns invoked by the issue of repatriation.

\subsection{Affect, identity politics and the rule of law}

In the legal debate, the crucial dividing line was crystallized in the concept of jurisdiction - as defined by belonging. Space assumed normative meanings that went beyond the issue of state territory. What was at stake was not merely an issue of whether the state authorities could operate beyond the territory of the state to help the Finnish individuals in the camp, but of whether the women should be helped or not. Affective association of the "convert" and the "jihadist", central to the narrative about the women as nonbelonging, foreign and dangerous, resulted in the emergence of legal subjectivities whose belonging (and right to belong) to the jurisdiction of the Finnish state was fundamentally contested. The bordering process thus assumed a distinctively legal form as an argument about which law, Finnish or international, was applicable. This had further ramifications as to how politicians and officials could exercise their powers.

In the beginning of December 2019, the tabloid newspaper Ilta-Sanomat reported that the Foreign Ministry was caught up in a scandal about efforts to repatriate the individuals from Al-Hol. According to the accusations, minister Haavisto had tried to pressure the head of department of consular services to take measures in his own name, without any formal decision by the minister or the government, to repatriate the children without their mothers. The critics claimed the minister was trying to both save the cake and eat it by trying to get the rescue operation running while avoiding any political ramifications. As the head of department disagreed and refused to follow the minister's orders, the minister attempted to take the matters concerning Al-Hol away from him and assigned another official to weigh up the situation in the camp and lead possible repatriation operations (Pöntinen et al. 2019).

Following the turmoil, minister Haavisto was heard by the Parliament's Foreign Affairs Committee, which voted 10 to 3 in favour of expressing its approval of the course of action taken by Haavisto and the ministry (Pöntinen et al. 2019). The MPs of the Finns Party were not satisfied with the explanations received at the hearing of the Committee, and claimed that a strong suspicion remained that the minister did not tell the truth to the committee and the Parliament. Shortly after that the opposition led by the Finns Party submitted an interpellation against the Government concerning minister 
Haavisto's actions and the government's position with regard to Finnish individuals in Al-Hol (Teivainen 2019b).

Following the interpellation by the opposition, minister Haavisto held a press conference, in which he denied that detailed plans existed to bring individuals home from Al-Hol. However, a confidential document from 21 November 2019, which contained a detailed draft, had already been leaked to the press (Stenroos 2019, YLE 2019). According to this document, the Foreign Ministry had a working group plan dated 15 November 2019, which was to guarantee the personal safety and fundamental rights of the children, and which called for the return to Finland from Al-Hol of "all individuals who agreed to repatriation". The chair of the operation is an employee of the Foreign Ministry, and the working group includes representatives of the Foreign Ministry, Interior Ministry, the Social Affairs and Health Ministry and the Defence Ministry. The document stresses the confidentiality and sensitivity "from security perspectives and an international dimension". It was signed by a high police commissioner.

Again, affect assumed a central role, this time in the turmoil about the appropriateness of the minister's course of action. The head of the consular department spoke to the press, explicitly linking the dispute about how the Al-Hol case was run to the atmosphere of the ministry and the leadership style of minister Haavisto, accusing the minister of creating a climate of fear at the ministry. According to the head of the consular services, this climate of fear was detrimental and would lead to a work culture which would eventually pose a serious risk to the rule of law (Sajari 2019, Teivainen 2019a). He further accused the minister of making illegal decisions. The episode led to an investigation about whether the minister exceeded his legitimate powers when he removed the case from the official. The investigation was completed by the National Bureau of Investigation and all material was handed over to the Constitutional Law Committee in July 2020. The Committee will deliver its statement towards the end of 2020 about whether or not it considers that the minister should be prosecuted. After that, Parliament will vote on the issue.

Interestingly, the public debate concerning the acts of the minister assumed yet another affectively securitized interpretation: the minister was accused of jeopardizing the safety of the Finnish citizenry and betraying them by secretly having preparations made to repatriate the women and children from Al-Hol. The alleged fear inside the ministry, an issue about the atmosphere of the workplace, became associated with all the other signs of fear circulating around the debate over the individuals in Al-Hol. The minister thus became associated with fear, betrayal and dictatorship, allowing those who accuse him to present themselves as acting for the common good. Again, the naming of the emotion emerged as central to the struggle about the interpretation and appropriate meaning of the situation. Similarly to the political debate depicted above, the invoking of interpretations of emotions was central here too. Rather than simply disagreeing with the ministry's decision to assist the individuals, the association of "fear" with the minister enabled the opponents of this particular policy to present themselves as acting for the security of the people and for the rule of law. 


\section{Conclusions}

In this article I have studied the Finnish political debate about justice concerning the women and children in the refugee camp of Al-Hol during a politically intense period. With a view to the historicity of the affective value of childhood, I have analysed how it became possible for political parties from left to right to refrain from taking any action in the face of the pain and suffering that Finnish children are being subjected to in the Al-Hol camp. Drawing on Ahmed's conceptualization of an affective economy, I suggested that these families are actively produced as objects of fear, which enables the utilization of various emotional practices (Scheer 2012) that support the contextualization of legal obligations as questions of security.

A racialized, non-belonging and essentially non-Finnish identity was affectively constructed to the mothers. Emotions articulated for example as compassion were mobilised in the process, with ambiguous outcomes. On the one hand, reference to compassion served the conservative agenda of attaching rights to worthiness, while on the other hand reference to compassion towards the figure of the innocent child served to isolate the children from their mothers. The process of bordering was essentially an affective one, in which the individuals in Al-Hol were constructed as outsiders, which assisted in the mainstreaming of the policies of the populist radical right. In the legal context, the affectively constructed identities of the mothers as non-belonging were relevant to how the issue of rights and legal obligations of the state became perceived as something belonging to the realm of international law rather than national law.

A legal framework, although taken to be objective and pre-existing in relation to the particular situations in which it is applied, will always be constructed from a particular perspective. As the notion of sentiment of justice (Bens 2018, Bens and Zenker 2019) demonstrates, affect is part of the interpretative framework already in the beginning, in the issue of how and where and in which legal field the case at hand should be situated. The goals of the agent constructing the legal framework with a specific situation in mind exist in the very construction of the framework, allowing the agent to make use of whatever gaps or spaces for interpretation there are - and there always are. Thus, the framework, while based on the same sources, is never entirely the same. As we saw, the flexibility of the system was immediately politicized.

Returning to the issue of positionality, I want to highlight again the centrality of performativity to how affect works, in legal as well as in other contexts. Performativity, the fact that affects and emotions both generate their objects and reiterate past associations, depends on historicity and is of crucial importance to how meaning is made affectively. It is perhaps here where the identities and social locations of participants in the public debate, myself included, become epistemically relevant as a question of constructing a standpoint. I noted that while it is true that certain aspects of my identity (being a lawyer, a mother etc.) probably proved relevant in motivating the research and directing attention, there are other trajectories and divisions in society that might be more relevant to constructing a standpoint in a research project that addresses the debate about the women and their children. As examples of such divisions, I brought up the different social locations historically deriving from the Finnish Civil War of 1918, as well as the polarized political climate that we are currently experiencing. Regarding these divisions, researchers are not outsiders but participants in the phenomena they study. 
Reflecting on one's own affective responses, and their possible social and historical origins, provides the research with more objectivity than a refusal to address them in the name of "objectivity".

In the public debate about the faith of the women and children, all discussants undoubtedly want to present themselves as acting out of compassion and love, rather than hate. But love - whether directed towards the worthy subject, the innocent child, or the very small child - leaves us with a question about divisions. This article has demonstrated, in accordance with my previous work (Mustasaari 2016), that the rights of the child can be mobilized in the same endeavour to differentiate between classes of persons worthy of rights. Child welfare and protection officials were prepared to receive children arriving from Al-Hol, but the plans to bring the children and their mothers to safety were torpedoed (Sillanpää 2019b). My fear is that this may have far-reaching ramifications. Those affected by the fragmentation of the subject of fundamental rights are not just "the terrorists"; they are any bodies that may become depicted as nonbelonging - let alone associated with terrorism.

\section{References}

\section{Academic literature}

Ahmed, S., 2014. The Cultural Politics of Emotion. $2^{\text {nd }}$ ed. Edinburgh University Press.

Bens, J., 2018. The Ethnography of Affect in Discourse Practice - Performing Sentiment in the Time Machine. In: A. Kahl, ed., Analyzing Affective Societies: Methods and Methodologies. Abingdon: Routledge.

Bens, J., and Zenker, O., 2019. Sentiment. In: J. Slaby and C. von Scheve, eds., Affective Societies: Key Concepts. Abingdon: Routledge.

Bruce-Jones, E., 2016. Race in the Shadow of Law: State Violence in Contemporary Europe. London: Routledge.

Charmaz, K., 2012. Writing feminist research. In: S.N. Hesse-Biber, ed., Handbook of Feminist Research: Theory and Praxis. London: Sage.

Coleman, J., and Cook, J., 2020. Shamima Begum, citizenship revocation and the question of due process. ICCT Perspectives [online], 17 July. The Hague: International Centre for Counter-Terrorism. Available from: https:/icct.nl/publication/shamima-begum-citizenship-revocation-and-thequestion-of-due-process/ [Access 10 September 2020].

Farnham, H., 2019. What the media circus surrounding Shamima Begum can teach us about gender and nation. Engenderings. LSE Gender Studies blog [online], 3 April. Available from: https://blogs.lse.ac.uk/gender/2019/04/03/gender_and_nation/ [Access 10 September 2020].

Frevert, U., 2010. Trust as Work. In: J. Kocka, ed., Work in a Modern Society: The German Historical Experience in Comparative Perspective. New York: Berghahn Books, 93108. 
Frevert, U., 2014a. Defining Emotions: Concepts and Debates over Three Centuries. In: U. Frevert et al., Emotional Lexicons: Continuity and Change in the Vocabulary of Feeling 1700-2000. New York: Oxford University Press, 1-31.

Frevert, U., 2014b. Emotional knowledge: Modern developments. In: U. Frevert et al., Emotional Lexicons: Continuity and Change in the Vocabulary of Feeling 1700-2000. New York: Oxford University Press, 260-273.

Fulton, H., 2005. Introduction: The power of narrative. In: H. Fulton (with R. Huisman, J. Murphet and A. Dunn), ed., Narrative and Media. Cambridge University Press.

Galonnier, J., 2015. The racialization of Muslims in France and the United States: Some insights from white converts to Islam. Social Compass [online], 62(4), 570-583. Available from: https://doi.org/10.1177/0037768615601966 [Access 13 November 2020].

Gozdecka, D.A., forthcoming, 2021. Visual Power, Representation and Migration Law. Edinburgh University Press.

Grasswick, H., 2018. Feminist Social Epistemology (First published Thu Nov 9, 2006; substantive revision Tue Jul 24, 2018). In: E. Zalta, ed., The Stanford Encyclopedia of Philosophy (Fall 2018 ed.) [online] Available from:

https://plato.stanford.edu/archives/fall2018/entries/feminist-social-epistemology/ [Access 13 November 2020].

Gregg, M., and Seigworth, G.J., 2010. The Affect Theory Reader. Durham: Duke University Press.

Haraway, D., 1988. Situated knowledges: The science question in feminism and the privilege of partial perspective. Feminist Studies, 14(3), 575-599.

Hellman, C.M.E., Monni, M., and Alanko, A.M., 2017. Declaring, shepherding, managing: The welfare state ethos in Finnish government programmes, 19502015. Research on Finnish society, 10(1), 9-22 .

Hiitola, J., 2015. Hallittu vanhemmuus: sukupuoli, luokka ja etnisyys huostaanottoasiakirjoissa [Governed parenthood: Out-of-home placements and gender, class and ethnicity]. Tampere University Press.

Hoffmann, C., 2010. Introduction. In: W. Bublitz and C. Hoffmann, eds., Narrative Revisited: Telling a Story in the Age of New Media. Amsterdam: John Benjamins.

International Center for the Study of Violent Extremism (ICSVE), 2019. SDF Needs Our Help Now as Another Woman in Camp Hol Killed by ISIS Enforcers. ICSVE [online], 1 October. Available from: https://www.icsve.org/sdf-needs-our-helpnow-as-another-woman-in-camp-hol-killed-by-isis-enforcers/ [Access 13 November 2020] (Originally published in Homeland Security Today).

Jensen, T.G., 2008. To Be “Danish", Becoming “Muslim": Contestations of National Identity? Journal of Ethnic and Migration Studies [online], 34(3), 389-409. Available from: https://doi.org/10.1080/13691830701880210 [Access 13 November 2020].

Jungar, A.C., and Jupskås, A.R., 2014. Populist Radical Right Parties in the Nordic Region: A New and Distinct Party Family? Scandinavian Political Studies [online], 
37(3), 215-238. Available from: https://doi.org/10.1111/1467-9477.12024 [Access 13 November 2020].

Kaarninen, M., 2008. Punaorvot 1918. Helsinki: Minerva.

Keskinen, S., 2016. From welfare nationalism to welfare chauvinism: Economic rhetoric, the welfare state and changing asylum policies in Finland. Critical Social Policy [online], 36(3), 352-370. Available from: https://doi.org/10.1177/0261018315624170 [Access 13 November 2020].

Keskinen, S., 2017. Securitized Intimacies, Welfare State and the "Other" Family. Social Politics [online], 24(2), 154-177. Available from: https://doi.org/10.1093/sp/jxx002 [Access 13 November 2020].

Kumar, D., 2015. Race, ideology, and empire. Dialectical Anthropology [online], 39(1), 121-128. Available from: https://doi.org/10.1007/s10624-015-9373-6 [Access 13 November 2020].

Labenski, S., 2020. Women's violence and the law: in consideration of Shamima Begum. LSE Women, Peace and Security blog [online], 30 March. Available from: http://eprints.lse.ac.uk/103903/1/WPS 2019 11_20 women s violence and the 1 aw.pdf [Access 10 September 2020].

Massumi, B., 2002. Parables for the Virtual. Durham: Duke University Press.

Matt, S.J., and Stearns, P.N., 2014. Doing Emotions History. Urbana: University of Illinois Press.

Mehra, T., 2019. European countries are being challenged in court to repatriate their foreign fighters and families. ICCT Perspectives [online], 7 November. The Hague: International Centre for Counter-Terrorism. Available from: https://icct.nl/publication/european-countries-are-being-challenged-in-court-torepatriate-their-foreign-fighters-and-families/ [Access 17 July 2020].

Miller, A., 2018. Kin-Work in a Time of Jihad: Sustaining Bonds of Filiation and Care for Tunisian Foreign Combatants. Cultural Anthropology [online], 33(4), 596-620. Available from: https://doi.org/10.14506/ca33.4.07 [Access 13 November 2020].

Moors, A., and Vroon-Najem, V., 2019. Converts, marriage, and the Dutch nation-state: Contestations about Muslim women's wellbeing. In: M. Tiilikainen, M. AlSharmani and S. Mustasaari, eds., Wellbeing of Transnational Muslim Families: Marriage, Law and Gender. London: Routledge, 22-38.

Mustasaari, S., 2016. Best interests of the child in family reunification - A citizenship test disguised? In: A. Griffiths, S. Mustasaari and A. Mäki-Petäjä-Leinonen, eds., Subjectivity, Citizenship and Belonging in Law: Identities and Intersections. Abingdon: Routledge, 124-145.

Mustasaari, S., 2017. Rethinking recognition: Transnational families and belonging in law. PhD Thesis. University of Helsinki.

Mustasaari, S., 2020. Finnish Children or "Cubs of the Caliphate"? Jurisdiction and State "Response-ability" in Human Rights Law, Private International Law and the Finnish Child Welfare Act. Oslo Law Review, 1/2020, 22-45. 
Nordensvard, J., and Ketola, M., 2015. Nationalist Reframing of the Finnish and Swedish Welfare States - The Nexus of Nationalism and Social Policy in Far-right Populist Parties. Social Policy \& Administration [online], 49(3), 356-375. Available from: https://doi.org/10.1111/spol.12095 [Access 13 November 2020].

Open Society Foundations (OSF), 2013. Somalis in Helsinki. Open Society Foundations [online], 21 November. Available from: https://www.opensocietyfoundations.org/sites/default/files/somalis-helsinki20131121.pdf [Access 2 November 2020].

Orozobekova, A., forthcoming, 2021. Women Joining Violent Islamist Entities in Syria and Iraq: The Case of Central Asia. NATO Science for Peace and Security Series.

Özyürek, E., 2015. Being German, Becoming Muslim: Race, Religion, and Conversion in the New Europe. Princeton University Press.

Paasonen, S., 2011. Carnal Resonance: Affect and Online Pornography. Cambridge, MA: The MIT Press.

Phoenix, A., 2013. Analysing Narrative Contexts. In: M. Andrews, M. Squire and M. Tamboukou, eds., Doing Narrative Research. London: Sage.

Puar, J., and Rai, A., 2002. Monster, Terrorist, Fag: The War on Terrorism and the Production of Docile Patriots. Social Text 20(3), 117-48.

Rastas, A., 2012. Reading History through Finnish Exceptionalism. In: K. Loftsdóttir and L. Jensen, eds., Whiteness and Postcolonialism in the Nordic Region: Exceptionalism, Migrant Others and National Identities. Farnham: Ashgate, 89-103.

Reddy, W.M., 2001. The Navigation of Feeling: A Framework for the History of Emotions. Cambridge, New York: Cambridge University Press.

Renard, T., and Coolsaet, R., 2018. Children in the Levant: Insights from Belgium on the dilemmas of repatriation and the challenges of reintegration. Security Policy Brief [online], nำ 98. Brussels: Egmont-Royal Institute for International Relations. Available from: https://biblio.ugent.be/publication/8569049/file/8569052.pdf [Access 12 September 2020].

Rosenwein, B.H., and Cristiani, R., 2018. What is the History of Emotions? Malden: Polity Books.

Scheer, M., 2012. Are Emotions a Kind of Practice (and Is That What Makes Them Have a History)? A Bourdieuan Approach to Understanding Emotion. History and Theory [online], 51(2), 193-220. Available from: https://doi.org/10.1111/j.14682303.2012.00621.x [Access 13 November 2020].

Schwander, T., 2019. Die Pflicht zur Rückholung Deutscher aus dem vormaligen ISGebiet. Neue Zeitschrift für Verwaltungsrecht, 17/2019, 1260.

Speckhard, A., 2020. Perspective: Ireland's Lisa Smith Is a Test Run on Repatriation of ISIS Women. Homeland Security Today [online], 14 January. International Center for the Study of Violent Extremism. Available from: https://www.hstoday.us/subject-matter-areas/counterterrorism/perspective- 
irelands-lisa-smith-is-a-test-run-on-repatriation-of-isis-women/ [Access 10 September 2020].

St. Pierre, E.A., 2000. Poststructural feminism in education: An overview. Qualitative Studies in Education [online], 13(5), 477-515. Available from: https://doi.org/10.1080/09518390050156422 [Access 13 November 2020].

Stearns, P.N., and Stearns, C.Z., 1985. Emotionology. Clarifying the History of Emotions and Emotional Standards. The American Historical Review [online], 90(4), 813-836. Available from: https://doi.org/10.2307/1858841 [Access 13 November 2020].

The Soufan Group, 2019. “The Dilemma of Repatriation” IntelBrief [online], 1 July. Available from: https://thesoufancenter.org/intelbrief-the-dilemma-ofrepatriation/ [Access 20 September 2019].

van Nieuwkerk, K., 2004. Veils and wooden clogs don't go together. Ethnos [online], 69(2), 229-246. Available from: https://doi.org/10.1080/0014184042000212876 [Access 13 November 2020].

van Wichelen, S., 2015. Scales of grievability: on moving children and the geopolitics of precariousness. Social \& Cultural Geography, 16(5), 552-566.

Wibben, A.T.R., 2011. Feminist Security Studies: A Narrative Approach. London, New York: Routledge.

Yuval-Davis, N., 2011. The Politics of Belonging: Intersectional Contestations. Thousand Oaks: Sage.

Yuval-Davis, N., Wemyss, G., and Cassidy, K., 2019. Bordering. Cambridge: Polity Press.

\section{Primary sources}

Addario, L., 2019. A humanitarian crisis emerges as ISIS falls in northern Syria. The National Geographic [online], 27 March. Available from:

https://www.nationalgeographic.com/culture/2019/03/humanitarian-crisis-isisfamilies-flee-to-syrian-refugee-camp/ [Access 16 November 2020].

Chulov, M., and McKernan, B., 2019. Hoda Muthana "deeply regrets" joining Isis and wants to return home. The Guardian [online], 17 February. Available from: https://www.theguardian.com/world/2019/feb/17/us-woman-hoda-muthanadeeply-regrets-joining-isis-and-wants-return-home [Access 11 November 2019].

Doctors Without Borders, 2019. Syria: Women and children suffer amid poor conditions in $\mathrm{Al} \mathrm{Hol} \mathrm{camp.} \mathrm{Doctors} \mathrm{Without} \mathrm{Borders} \mathrm{[online],} 19$ May. Available from: https://www.doctorswithoutborders.org/what-we-do/newsstories/news/syria-women-and-children-suffer-amid-poor-conditions-al-holcamp [Access 11 November 2019].

Hubbard, B., 2019. Wives and Children of ISIS: Warehoused in Syria, Unwanted Back Home. The New York Times [online], 4 July. Available from: https://www.nytimes.com/2018/07/04/world/middleeast/islamic-state-familiessyria.html [Access 16 November 2020]. 
International Rescue Committee, 2019. Data analyzed by the IRC reveals staggering health and humanitarian needs of children in Al Hol camp, Northeast Syria-urging repatriation of foreign children [online]. Press Release. 16 September. Available from: https://www.rescue.org/press-release/data-analyzed-irc-reveals-staggeringhealth-and-humanitarian-needs-children-al-hol [Access 16 November 2020].

Koskinen, A., 2019. Professori arvostelee Suomen asennetta Isis-äitien lapsia kohtaan: “En osaa pitää kymmentä naista kauhean suurena vaarana Suomen turvallisuudelle". YLE [online], 27 June. Available from: https://yle.fi/uutiset/310849538 [Access 16 November 2020].

Kuronen, A., 2019a. Äiti vei Sumeyan Suomesta Isisin alueelle tokaluokkalaisena tyttö päätyi naimisiin 13-vuotiaana ja kertoo nyt tarinansa Ylelle. YLE [online], 23 September. Available from: https://yle.fi/uutiset/3-10984963 [Access 16 November 2020].

Kuronen, A., 2019b. Yle Isis-leirillä Syyriassa: Leirillä on jopa 44 suomalaista, kertovat suomalaisnaiset videolla - “Haluamme takaisin Suomeen". YLE [online], 23 May. Available from: https://yle.fi/uutiset/3-10798807 [Access 16 November 2020].

McKernan, B., 2019. Defiant women and dying children: Isis' desert legacy. The Guardian [online], 1 March. Available from: https://www.theguardian.com/world/2019/mar/01/defiant-women-and-dyingchildren-isis-desert-legacy-al-hawl-refugee-camp [Access 15 April 2019].

Newmark, Z., 2019. Netherlands does not have to help kids trapped in Syria: Appellate Court. NL Times [online], 22 November. Available from:

https://nltimes.nl/2019/11/22/netherlands-help-kids-trapped-syria-appellate-court [Access 15 December 2019].

Pöntinen, P., Heiskanen, H., and Pärssinen, M., 2019. Eduskunnan ulkoasiainvaliokunta äänesti - enemmistö tuki ulkoministeri Haavistoa al-Holin leiriä koskevissa asioissa. YLE [online], 3 December. Available from: https://yle.fi/uutiset/3-11100765 [Access 3 December 2019].

Sajari, P., 2019. Konsulipäällikkö Pasi Tuominen arvostelee HS:n haastattelussa ankarasti ulkoministeri Haavistoa: syyttää pelolla johtamisesta ja lainvastaisesta päätöksestä. Helsingin Sanomat [online], 6 December. Available from: https://www.hs.fi/politiikka/art-2000006333612.html [Access 7 December 2019].

Sillanpää, S., 2019a. Seitsemän sisarta. Helsingin Sanomat [online], 24 May. Available from: https://www.hs.fi/kuukausiliite/art-2000006118007.html [Access 15 July 2019].

Sillanpää, S., 2019b. Suomi on jo neuvotellut al-Holin suomalaislasten kotiuttamisesta Kurdipoliitikko HS:lle: Lapsia ei voi erottaa äideistään pakolla. Helsingin Sanomat [online], 10 December. Available from: https://www.hs.fi/politiikka/art2000006338671.html [Access 10 December 2019].

Staff Writer with AFP, 2019. Belgium court orders repatriation of ISIS-linked family from Roj camp in Syria. The Defense Post [online], 31 October. Available from: https://thedefensepost.com/2019/10/31/belgium-isis-family-repatriation-roj-syria/ [Access 5 January 2020]. 
Stenroos, M., 2019. Suomella on "melko täsmällinen" suunnitelma, miten al-Holin leiriläiset siirrettäisiin Suomeen. YLE [online], 9 December. Available from: https:/yle.fi/uutiset/3-11109383 [Access 9 December 2019].

Teivainen, A., 2019a. HS: Head of consular services criticises leadership style of Haavisto. Helsinki Times [online], 6 December. Available from:

https://www.helsinkitimes.fi/finland/finland-news/politics/17068-hs-head-ofconsular-services-criticises-leadership-style-of-haavisto.html [Access 9 December 2019].

Teivainen, A., 2019b. YLE: Chancellor of Justice to look into actions of Haavisto and Ministry for Foreign Affairs. Helsinki Times [online], 10 December. https://www.helsinkitimes.fi/finland/finland-news/domestic/17083-ylechancellor-of-justice-to-look-into-actions-of-haavisto-and-ministry-for-foreignaffairs.html [Access 10 December 2019].

YLE, 2019. Yle sources: Foreign Ministry prepped plan for Finns who wanted to leave al-Hol refugee camp. YLE News [online], 11 December. Available from: https:/yle.fi/uutiset/osasto/news/yle sources foreign ministry prepped plan fo $\underline{r}$ finns who wanted to leave al-hol refugee camp/11113908 [Access 11 December 2019].

Case law

Oberverwaltungsgericht Berlin-Brandenburg, Decision 6 November 2019, ECLI:DE:OVGBEBB:2019:1106.OVG10S43.19.00.

The Chancellor of Justice, Decision 9 October 2019, Dnro OKV/998/1/2019, OKV/1082/1/2019, OKV/1089/1/2019, OKV/1104/1/2019, OKV/1109/1/2019, OKV/1131/1/2019, OKV/1132/1/2019, OKV/1134/1/2019, OKV/1171/1/2019, OKV/1186/1/2019, OKV/1256/1/2019, OKV/1257/1/2019, OKV/1561/1/2019. 